\title{
Immunoglobulin E epitope mapping by microarray immunoassay reveals differences in immune response to genetic variants of caseins from different ruminant species
}

\author{
M. Lisson, ${ }^{*}$ N. Novak, + and G. Erhardt ${ }^{* 1}$ \\ *Department of Animal Breeding and Genetics, Justus-Liebig University, 35390 Gießen, Germany \\ †Department of Dermatology and Allergy, University of Bonn Medical Center, 53105 Bonn, Germany
}

\begin{abstract}
The allergenicity of the caseins $(\mathrm{CN})$, one of the major allergens in cow milk, is well characterized and their immunoglobulin E ( $\operatorname{IgE}$ )-binding epitopes have been identified. However, investigations about the allergenic potential of the genetic variants occurring in the caseins are lacking. Therefore, this study determined the influence of the genetic polymorphism on $\mathrm{IgE}$ binding to epitopes of bovine casein variants. Furthermore, differences in $\operatorname{IgE}$ binding between epitopes of goats and water buffaloes were analyzed. A set of 187 peptides, covering the previously identified sequential IgE-binding epitopes of $\alpha_{\mathrm{S1}^{-}}, \alpha_{\mathrm{S}^{-}}, \beta-$, and $\kappa-\mathrm{CN}$ variants from cows and the corresponding homologous peptides of water buffaloes and goats, were synthesized and tested by means of peptide microarray for $\operatorname{IgE}$ binding, using sera from 16 cow milk-sensitized individuals. Seven of the 16 sera samples showed positive signals on microarrays and were included in this study. In $5 \alpha_{\mathrm{S}_{1}} \mathrm{CN}$ variants (A, B, C, E, and I), the AA substitution or deletion affected the immunoreactivity of epitopes AA 4 to 23 , AA 17 to 36 , AA 83 to 102, AA 173 to 192, and AA 175 to 194, as well as of the variant-specific peptides AA 184 to 196, AA 187 to 199, AA 174 to 193, and AA 179 to 198, which were found to resist gastrointestinal digestion. Variation in $\mathrm{IgE}$ binding was further detected for peptides AA 103 to 123 and AA 108 to 129 of $3 \beta-\mathrm{CN}$ variants $\left(\mathrm{A}^{1}, \mathrm{~A}^{2}\right.$, and $\left.\mathrm{B}\right)$. The majority of sera showed IgE binding to $\alpha_{S_{1}-} \mathrm{CN}$ peptides of cows and the homologous counterpart of goats and water buffaloes. However, $\alpha_{S_{1}}$ and $\beta-\mathrm{CN}$ epitopes from goats and water buffaloes had lower immunoreactivity than those of cows, but, in some cases, higher or exclusive IgE binding was observed. The results of this study indicate that genetic variants of the caseins differ in their allergenicity. This might be useful in the search for a suitable protein source for cow milk-allergic patients. In addition, milk from water buffaloes and goats
\end{abstract}

Received August 9, 2013.

Accepted December 8, 2013.

${ }^{1}$ Corresponding author: Georg.Erhardt@agrar.uni-giessen.de harbor an allergenic potential due to cross-reactivity of $\operatorname{IgE}$ antibodies with cow milk caseins and are, therefore, not an acceptable alternative in the nutrition of cow milk-allergic patients.

Key words: casein variant, immunoglobulin E epitope, milk allergy, peptide microarray

\section{INTRODUCTION}

From a nutritional point of view, cow milk gains considerable attention, as it provides a wide range of essential nutrients, in particular proteins, fat, vitamins, and minerals. In contrast, cow milk belongs to the most common nutritive source of allergens during infancy and early childhood. Cow milk allergy (CMA) affects 2 to $3 \%$ of infants (Skripak et al., 2007) and approximately $0.1 \%$ of adults (Osterballe et al., 2005) who are typically sensitized to several cow milk proteins (CMP). The majority of children with CMA achieve tolerance toward cow milk, although the age of clinical recovery has differed among various studies (Savilahti and Savilahti, 2013). Reports suggest that in most children, CMA resolves by 3 to 5 yr of age, but outgrowing CMA can develop even later (Skripak et al., 2007; Savilahti and Savilahti, 2013). Cow milk allergy is mostly mediated by milk protein-specific IgE antibodies that react with the allergenic epitopes on milk proteins. The 4 caseins $\alpha_{\mathrm{S}^{-}}, \alpha_{\mathrm{S} 2^{-}}, \beta-$, and $\kappa^{-} \mathrm{CN}$ were confirmed to be the major allergens in cow milk, with $\alpha_{\mathrm{S} 1}-\mathrm{CN}$ found to be more allergenic than $\alpha_{\mathrm{S}^{-}}, \beta-$, and $\kappa$-CN (Shek et al., 2005; Gaudin et al., 2008). By using SPOT-membranebased or microarray immunoassays and sera from CMA patients, a large number of IgE-binding epitopes 8 to 24 AA in length have been identified in the 4 caseins (Chatchatee et al., 2001a,b; Busse et al., 2002, Cerecedo et al., 2008; Lin et al., 2009). Recent studies demonstrated that peptides resulting from in vitro gastrointestinal digestion of milk proteins still contain some of these IgE-binding epitopes (Dupont et al., 2010a,b; Lisson et al., 2013, 2014). This might provide an explanation for the high sensitization rate to the caseins, even though they are very rapidly digestible proteins. 
Within the caseins, noticeable genetic variation has been identified, which is caused by substitutions or deletions of AA. So far, a total of 39 casein variants have been determined on the protein and DNA level, with important differences among species and breeds within the Bos genus (Caroli et al., 2009).

To date, the only treatment for CMA is strict avoidance of CMP. This is very difficult, as milk proteins are used as additives or processing aids and, therefore, a large number of food products contain remaining amounts of CMP. Furthermore, infant formulas based on CMP still may provoke allergic reactions in selected patients, as residual allergenic activity has been reported in partially and extensively hydrolyzed formulas (Ragno et al., 1993; de Boissieu et al., 1997; Hoffman and Sampson, 1997). Moreover, CMP hydrolysates are disadvantaged by their bitter taste and the requirement of additional emulsifiers. Thus, the identification of a suitable protein source as well as the search for options to eliminate the allergenicity in milk products or infant formulas is of great importance. Genetic variants of milk proteins are not considered when discussing the allergenic potential of bovine milk. However, detection of CMP variants with reduced allergenicity may contribute to find adequate alternatives for allergic patients. Genetic polymorphisms of milk proteins are of increasing interest in animal breeding because of their significant effect on milk production traits and on cheese-making properties (Martin et al., 2002; Heck et al., 2009). In addition, milk protein variants are also important in human nutrition, as they represent a reservoir of bioactive peptides (angiotensin I-converting enzyme inhibitory peptides, casomorphins, and caseinophosphopeptides), which affect the nutritional value of milk (Jinsmaa and Yoshikawa, 1999; Weimann et al., 2009; Tulipano et al., 2010).

On the basis of the allergenic epitopes previously identified, the present study investigated the influence of the genetic polymorphisms on the IgE-binding properties of epitopes from $\alpha_{\mathrm{S1}^{-}}, \alpha_{\mathrm{S}^{-}}, \beta-$, and $\kappa$-CN variants. This study also aimed to determine if variant-specific casein peptides resisting in vitro gastrointestinal digestion still retain IgE-binding properties and differ in their allergenic potential. In addition, differences in $\mathrm{IgE}$ binding between epitopes of 2 mammalian species (goats and water buffaloes) were analyzed because there has been an increasing focus on the use of proteins from non-bovine milk as a possible alternative to cow milk.

\section{MATERIALS AND METHODS}

\section{Sera from Patients with CMA}

The screening was performed with sera from 16 patients ( 6 females, 8 males, and 2 unknown; 8 mo to 52 yr old) who had a positive skin prick test reaction to cow milkor specific IgE antibodies to cow milk, or both. The sera were obtained from the University Hospitals Bonn and Marburg (Germany). The patients had milk-specific IgE antibodies ranging from 4.5 to $>100 \mathrm{kU}_{\mathrm{A}} / \mathrm{L}$ (where $\mathbf{U}_{\mathrm{A}}=$ allergen-specific units), as measured with the ImmunoCAP System (Thermo Scientific, Freiburg, Germany). Only 7 (1 female, 5 males, and 1 unknown; 8 mo to $35 \mathrm{yr}$ old; $\operatorname{IgE}>100 \mathrm{kU}$ A $/ \mathrm{L}$ ) of the 16 sera, which were characterized by an $\operatorname{IgE}$ titer $\geq 95.5 \mathrm{kU}_{\mathrm{A}} / \mathrm{L}$, showed positive signals on microarray and were included in the current study. This study was approved by the local ethical review committees of the Justus-Liebig-University Gießen and the University of Bonn, Germany.

\section{Synthesis and Printing of Casein Peptides}

To investigate the role of genetic polymorphism as well as interspecies differences on the epitope structure, a set of 187 peptides, 11 to $20 \mathrm{AA}$ in length, covering the previously determined sequential IgE-binding epitopes of $\alpha_{\mathrm{S}^{-}}, \alpha_{\mathrm{S}^{-}}, \beta-$, and $\kappa_{-} \mathrm{CN}$ variants from cows and the corresponding homologous peptides of water buffaloes and goats as well as casein peptide variants, which were shown to resist gastrointestinal digestion (Lisson et al. 2013, 2014), were synthesized as described below (Table 1). Moreover, 36 peptides were synthesized with a phosphorylated serine residue and 1 peptide with a phosphorylated threonine residue. A total of 9 of these 37 peptides were spotted on the microarray without the phosphorylation to study the influence of posttranslational modifications on the immunoreactivity of the epitopes (Table 1). All peptides were synthesized in a stepwise manner on a cellulose membrane by using the SPOT synthesis technology (Frank and Overwin, 1996; Wenschuh et al., 2000). The peptide library and 3 control spots (human IgG, mouse IgE, and human IgE) were spotted in triplicate on each glass slide using a microarray printing system (JPT Peptide Technologies GmbH, Berlin, Germany). This gave a general microarray layout with 3 identical subarrays.

\section{IgE-Binding Assays}

The determination of peptide antibody binding was performed by RepliTope analysis (JPT Peptide Technologies $\mathrm{GmbH}$ ). The array slides were first incubated with blocking buffer (SmartBlock; Candor Bioscience GmbH, Wangen, Germany) for $60 \mathrm{~min}$. Then, they were placed into a microarray processing station (Tecan HS4800; Tecan Group Ltd., Männedorf, Switzerland) and incubated with $200 \mu \mathrm{L}$ of the patient's serum, diluted 1:100 in diluent buffer [SuperBlock Tris-buffered 
Table 1. The AA sequence of peptides spotted on the microarray

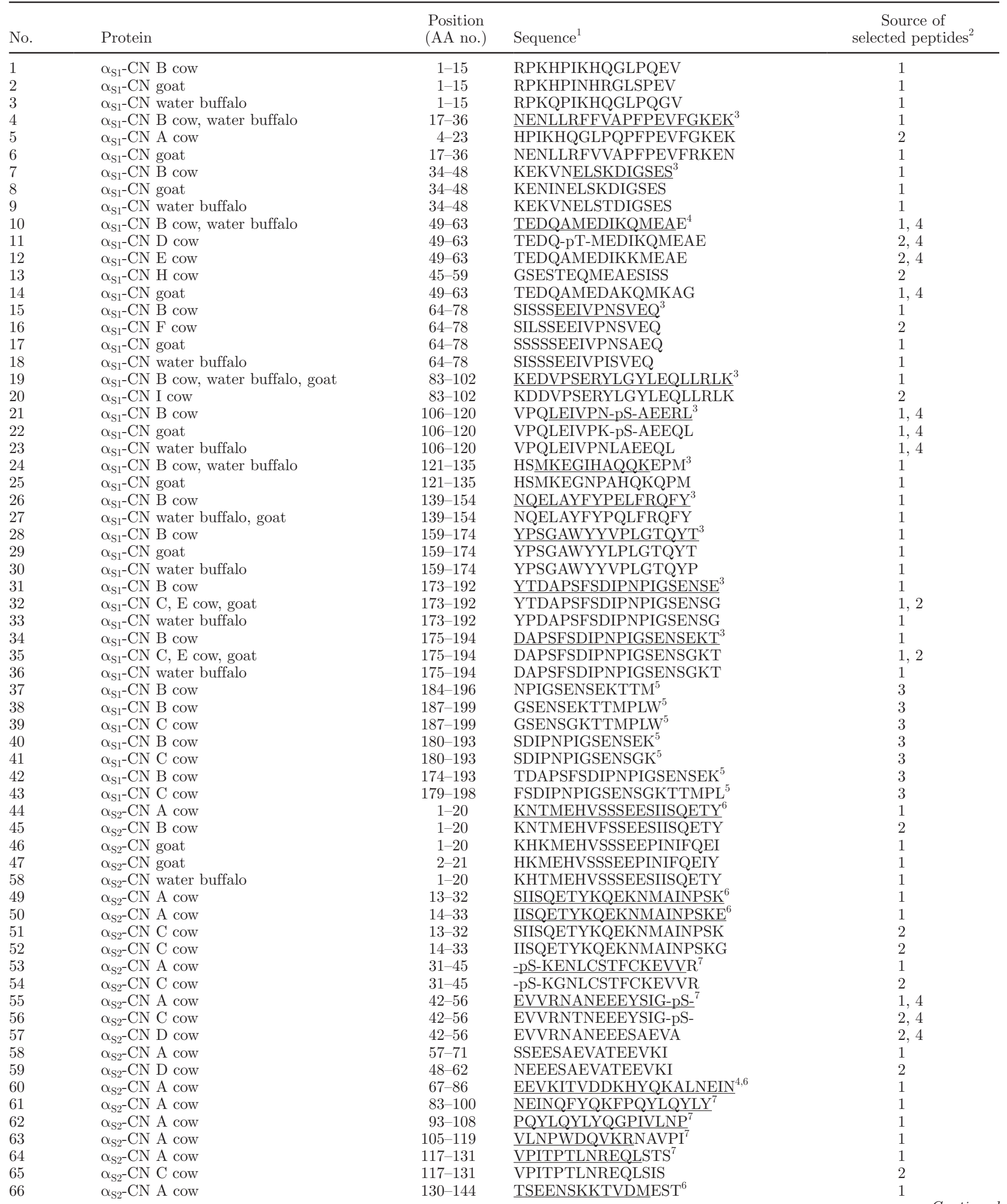


Table 1 (Continued). The AA sequence of peptides spotted on the microarray

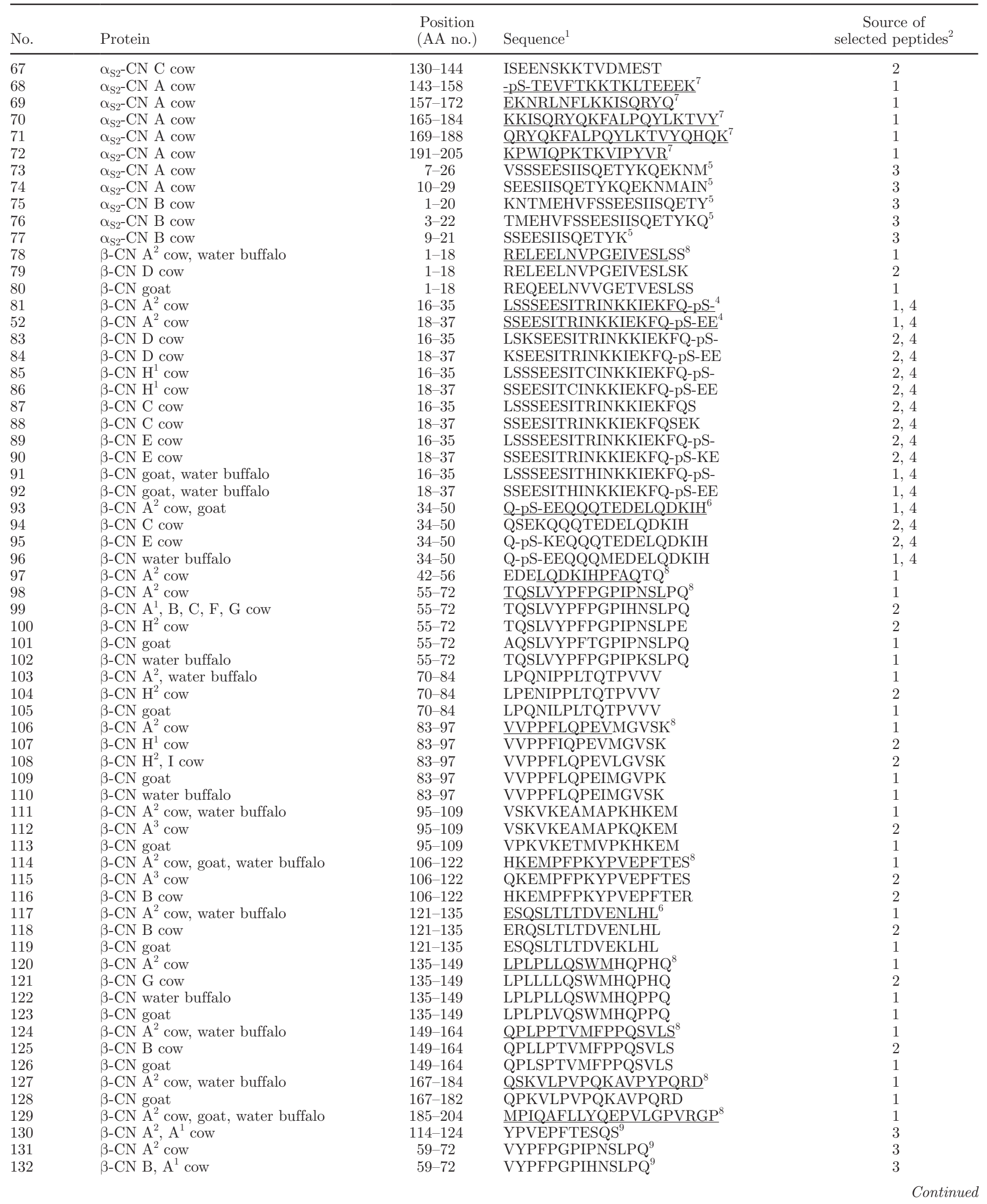


Table 1 (Continued). The AA sequence of peptides spotted on the microarray

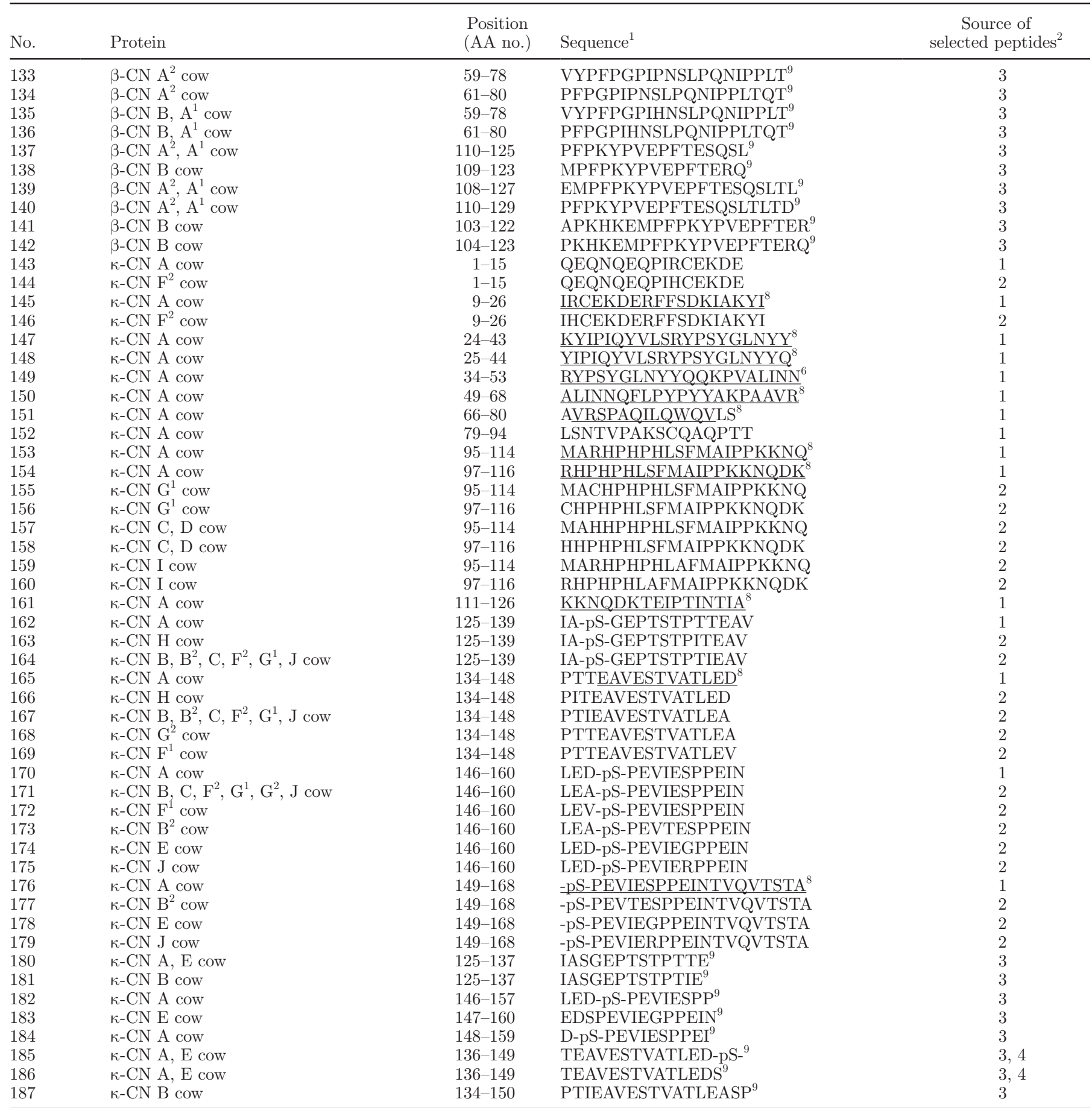

${ }^{1}$ Peptides previously reported as IgE-binding epitopes are underlined. Phosphorylated peptides are indicated as -pS- or -pT-.

${ }^{2} 1=$ peptides described in cattle; $2=$ bovine genetic variant; $3=$ peptides resisting gastrointestinal digestion; $4=$ peptides with different phosphorylation levels.

${ }^{3}$ Chatchatee et al. (2001a).

${ }^{4}$ Lin et al. (2009).

${ }^{5}$ Lisson et al. (2014).

${ }^{6}$ Cerecedo et al. (2008).

${ }^{7}$ Busse et al. (2002).

${ }^{8}$ Chatchatee et al. (2001b).

${ }^{9}$ Lisson et al. (2013). 
Table 2. Sera of cow milk-allergic patients reacting with peptides of $\alpha_{\mathrm{S}^{-}}, \beta-$, and $\kappa$-CN variants and differences in $\operatorname{IgE}$ binding between variantspecific peptides and corresponding reference peptides ${ }^{1}$

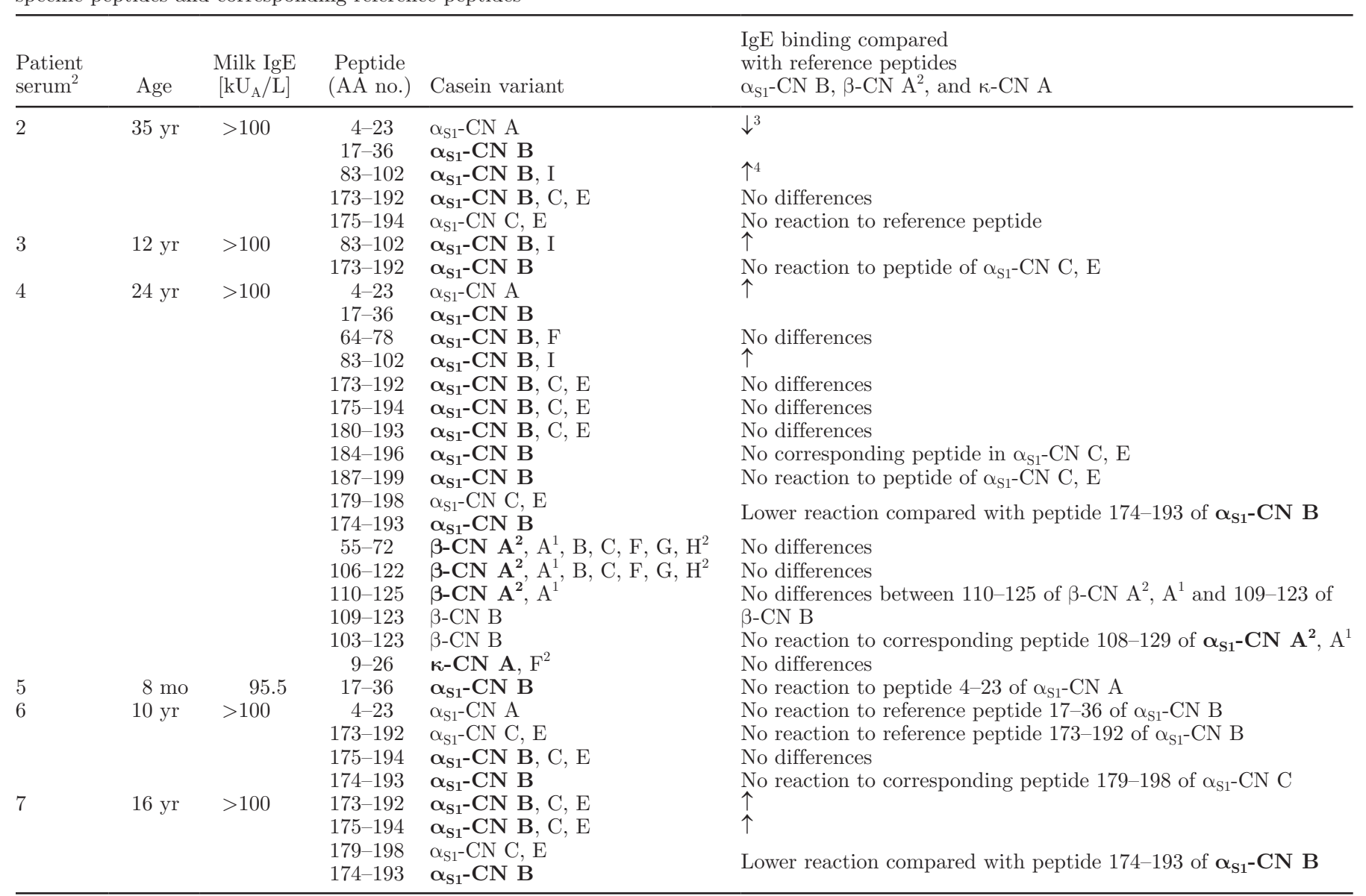

\footnotetext{
${ }^{1}$ Reference proteins are shown in bold.

${ }^{2}$ Serum 1 (age unknown; $>100 \mathrm{kU}_{\mathrm{A}} / \mathrm{L}$, where $\mathrm{U}_{\mathrm{A}}=$ allergen-specific units) showed no reaction with any of the casein variant peptides.

${ }^{3} \downarrow=$ decreased binding.

${ }^{4} \uparrow=$ increased binding.
}

saline (TBS); Pierce International, Rockford, IL], and with diluent buffer only as control for $2 \mathrm{~h}$. Subsequently, the peptide microarray was washed 3 times with 50 $\mathrm{m} M$ TBS buffer, including $0.1 \%$ Tween 20 (pH 7.2). Specific human IgE binding was detected by incubation with SureLight allophycocyanin-labeled secondary antihuman IgE (Abcam, Cambridge, UK) at a final concentration of $1 \mu \mathrm{g} / \mathrm{mL}$ in diluent buffer. Control incubation with secondary antibody only was performed in parallel. Afterward, 3 washing steps with $50 \mathrm{~m} M$ TBS buffer, including $0.1 \%$ Tween $20(\mathrm{pH} 7.2)$ were carried out, which were followed by a washing step with $3 \mathrm{mM}$ saline-sodium citrate buffer ( $\mathrm{pH}$ 7.0). Finally, peptide microarrays were dried using a nitrogen stream.

\section{Signal Detection and Data Analysis}

The peptide microarrays were scanned with the GenePix Scanner 4300SL50 (Axon Instruments, Concord,
ON, Canada). Images were saved electronically in tagged image file format (*.tif). Image analysis was performed using the spot-recognition software GenePix Pro 6.1 (Axon Instruments), which showed the signal intensity (light units) as single measurements for each peptide. Each spot feature was analyzed for total intensity and background intensity. For data tables and diagrams, the mean value of all 3 instances on the microarray was calculated. In case the standard deviation divided by the mean value was larger than 0.5 , the mean of the 2 closest values was used instead. Negative controls were used to define background noise. The fluorescent intensity of each peptide was determined by subtracting the mean intensity of the corresponding peptide spots from control incubation without serum. Immunoglobulin E binding was considered positive if signal intensities were above the lower limit of detection, meaning that ratios of signal-to-background noise intensities were greater than a minimum threshold of 1.5 . 

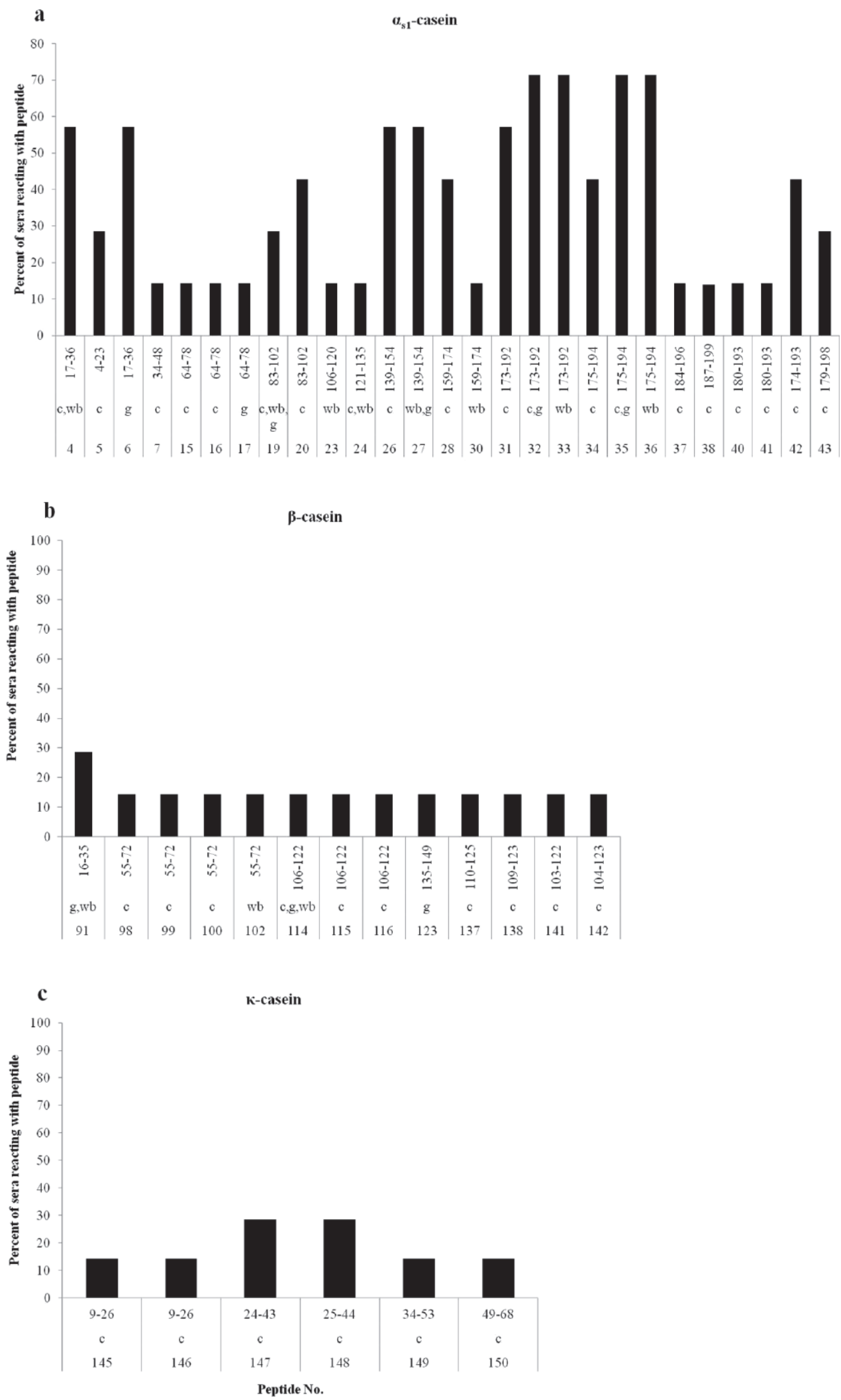

Figure 1. Immunoglobulin E binding pattern of cow milk-allergic patients to peptides of $\alpha_{\mathrm{S} 1}-\mathrm{CN}$ (a), $\beta$-CN (b), and $\kappa$-CN (c) from cows, goats, and water buffaloes. The bars indicate the percentage of sera showing IgE binding to peptides (represented by AA residues, number, and species). $\mathrm{c}=$ cow; $\mathrm{g}=$ goat; $\mathrm{wb}=$ water buffalo. 

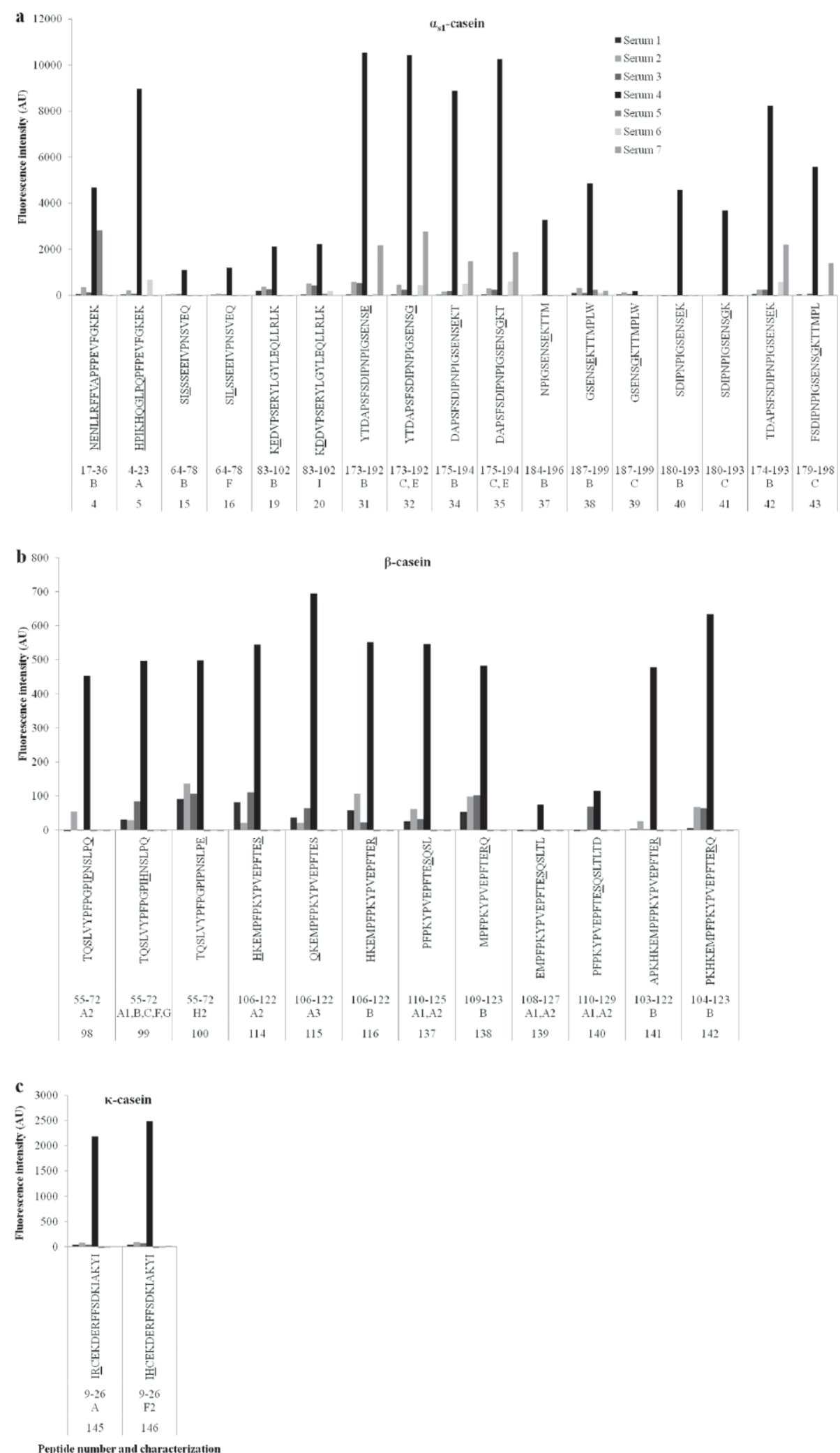

Figure 2. Differences in IgE binding between epitopes (represented by AA residues, number, and casein variant) of $\alpha_{\mathrm{S} 1}$-CN (a), $\beta$-CN (b), and $\kappa-\mathrm{CN}(\mathrm{c})$ variants from cows, using 7 sera with cow milk-specific IgE values $>100 \mathrm{kU}_{\mathrm{A}} / \mathrm{L}$, where UA = allergen-specific units. Differences in AA sequence between the reference peptides and the mutated peptides are underlined. The mean fluorescence intensity (arbitrary units, AU) of the 3 subarrays on the microarray for each peptide is presented. 

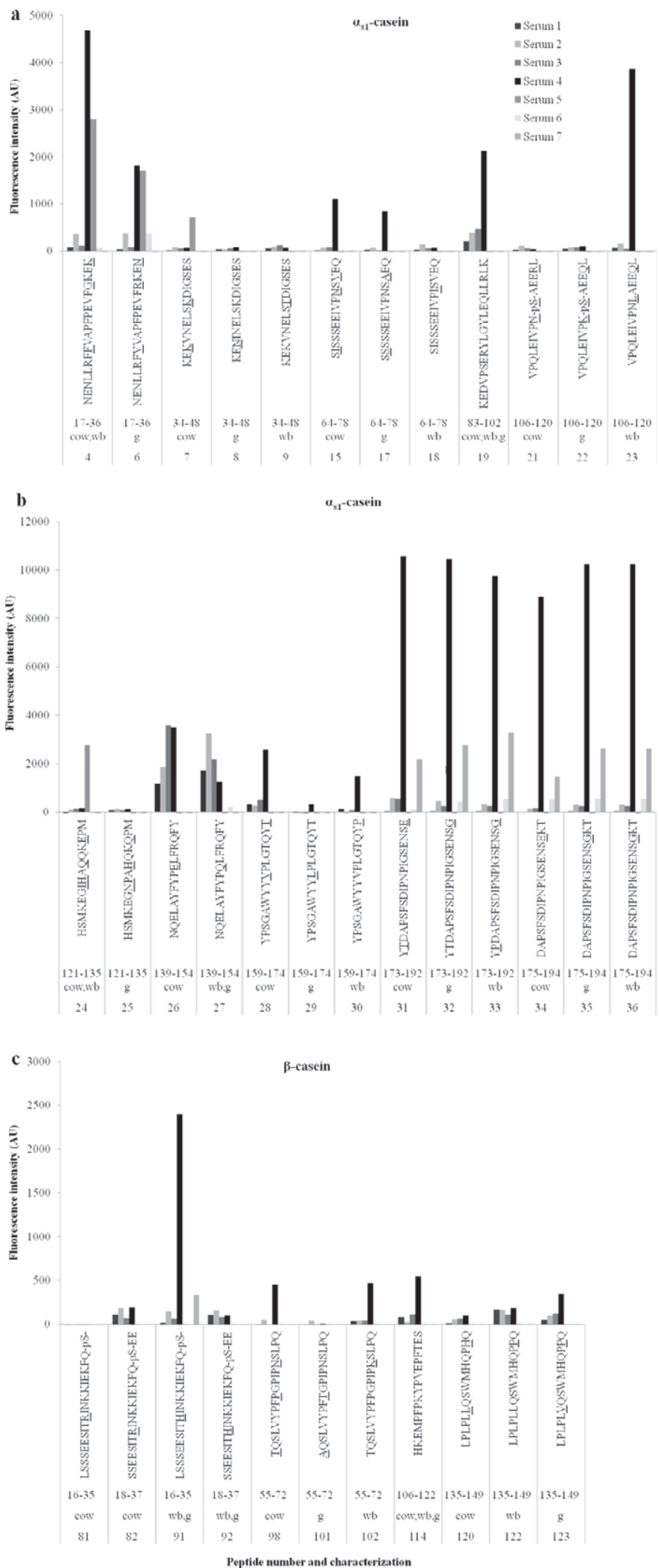

Figure 3. Differences in IgE binding between epitopes (represented by AA residues, number, and species) of $\alpha_{\mathrm{S1}}-\mathrm{CN}$ (a and b) and $\beta$-CN (c) from cows, goats, and water buffaloes, using 7 sera with cow milk-specific IgE values $>100 \mathrm{kU} / \mathrm{L}$, where UA $=$ allergen-specific units. Modifications in AA sequence between peptides of the 3 species are underlined. The mean fluorescence intensity (arbitrary units, AU) of the 3 subarrays on the microarray for each peptide is presented. $\mathrm{g}=$ goat; wb = water buffalo. 


\section{RESULTS}

\section{Identification of IgE-Binding Epitopes in Patient Sera Samples}

Among the sera samples tested in this study, IgE binding to at least 1 of the casein peptides occurred in all samples. A total of 46 casein peptides $\left(27 \alpha_{S^{-}}\right.$ $\mathrm{CN}$ peptides, $13 \beta$-CN peptides, and $6 \kappa$-CN peptides) were recognized by $\operatorname{IgE}$ antibodies from the different sera samples (Figure 1a, b, and c). All sera showed IgE binding to $\alpha_{\mathrm{S}_{1}} \mathrm{CN}$ peptides. It was the most frequently detected milk allergen, whereas no significant $\operatorname{IgE}$ binding was found for $\alpha_{\mathrm{S}_{2}} \mathrm{CN}$ peptides. The $\alpha_{\mathrm{S}^{-}} \mathrm{CN}$ peptides AA 17 to 36, AA 139 to 154, AA 173 to 192, and AA 175 to 194 of cows, goats, and water buffaloes reacted with $\mathrm{IgE}$ antibodies from at least $50 \%$ of the patient sera samples and, thus, represented the major IgE-binding epitopes (Figure 1a). The $\alpha_{\mathrm{S}_{1}} \mathrm{CN}$ peptides AA 83 to 102, AA 159 to 174, AA 174 to 193, and AA 175 to 194 from cows were recognized by 3 of the 7 positive sera. The $\alpha_{\mathrm{SI}^{-}} \mathrm{CN}$ peptides AA 4 to 23 (cow), AA 83 to 102 (goat and water buffalo), AA 179 to 198 (cow), and the $\beta$-CN peptide AA 16 to 35 (goat and water buffalo), as well as the $\kappa-\mathrm{CN}$ peptides AA 24 to 43 (cow) and AA 25 to 44 (cow) were identified in 2 sera samples (Figure 1a, b, and c). The other peptides of $\alpha_{\mathrm{S1}^{-}}, \beta$-, and $\kappa$-CN, giving positive signals on the microarray, displayed only binding to individual sera, particularly to serum 4 .

Only in 1 serum was an influence observed of the posttranslational modification on the immunoreactivity of the epitopes for the $\alpha_{\mathrm{S} 1}$-CN peptide AA 106 to 120 of the water buffalo (Figure $3 \mathrm{a}$ ). The IgE response to the peptide lacking the phosphorylated serine residue was $86 \%$ higher than to the phosphorylated peptides of cows and goats. The other sera showed no variation in the immunoreactivity between the peptides carrying phosphorylated serine residues or not.

\section{Identification of Variant-Specific Differences on the Epitope Structure}

The genetic variation affects the IgE-binding epitope structure of the caseins without inducing changes in $\operatorname{IgE}$ binding by the majority of sera (Table 2; Figure 2). Nevertheless, as indicated in Figure 2, some of the mutated epitopes led to abrogation or decreased or increased $\operatorname{IgE}$ binding in individual sera $(\geq 15 \%$ of $\operatorname{IgE}$ binding remaining compared with the reference peptide).

In $4 \alpha_{\mathrm{S}_{1}} \mathrm{CN}$ variants (A, C, E, and I), 1 deletion and 3 AA exchanges influenced the immunoreactivity of 5 epitopes (Figure 2a). Due to the deletion of AA 14 to 26 in $\alpha_{\mathrm{S} 1}-\mathrm{CN}$ A, epitope AA 4 to 23 differs in $10 \mathrm{AA}$ from the reference epitope AA 17 to 36 in $\alpha_{\mathrm{S}_{1}} \mathrm{CN}$ B. Thus, for peptide AA 4 to 23 of $\alpha_{\mathrm{S}_{1}}$ CN A, a loss of $\operatorname{IgE}$ binding could be observed in serum 5 , a decrease in $\operatorname{IgE}$ binding in serum 2 , and an increase in IgE binding in serum 4 compared with the reference peptide. Serum 6 reacted only with the peptide of $\alpha_{S_{1}}$ CN A, but showed no $\operatorname{IgE}$ binding to the reference peptide.

The AA substitutions characterizing epitopes AA 83 to 102 of $\alpha_{S_{1}}$ CN I as well as AA 173 to 192 and AA 175 to 194 of $\alpha_{\mathrm{SI}^{-}} \mathrm{CN} \mathrm{C}$ and $\mathrm{E}$ resulted in a loss of $\mathrm{IgE}$ binding in serum 3 and increased IgE binding in sera 2, 3, 4, and 7. In contrast to peptides AA 173 to 192 and AA 175 to 194 of $\alpha_{S_{1}}$ CN C and E, IgE binding to the corresponding peptides of $\alpha_{\mathrm{S}_{1}} \mathrm{CN} \mathrm{B}$ was eliminated by the AA substitution occurring at position 192 (sera 2 and 6). In 3 sera, the AA exchanges had no significant effect on the immunoreactivity of epitopes AA 64 to 78 (serum 4), AA 173 to 192 (sera 2 and 4), and AA 175 to 194 (sera 4 and 6). Both the mutated peptide as well as the reference peptide displayed similar IgE-binding intensities on the peptide microarray (Figure 2a).

Five of the 7 peptides resulting from gastrointestinal digestion of $\alpha_{\mathrm{S}_{1}} \mathrm{CN} B$ and $\mathrm{C}$ showed positive $\operatorname{IgE}$ binding on the microarray in 3 sera (Figure 2a). The AA substitution did not cause a change in the immunoreactivity of peptides AA 180 to 193 of $\alpha_{\mathrm{S}_{1}} \mathrm{CN}$ B and $\mathrm{C}$ in serum 4 . However, important differences in IgE binding were detected for peptides AA 187 to 199 and 179 to 198 of $\alpha_{\mathrm{S1}^{-}} \mathrm{CN} \mathrm{C}$ and the corresponding peptides of $\alpha_{\mathrm{S}_{1}}$-CN B because sera 4,6 , and 7 revealed significantly higher or exclusive IgE binding to peptides of $\alpha_{\mathrm{S}^{-}} \mathrm{CN}$ B.

As indicated in Figure 2b, the highest signal intensity of the responses against the different $\beta$-CN peptides were almost 1,500\% lower (700 versus 11,000 arbitrary units) compared with the highest signals obtained for peptides of $\alpha_{S_{1}}-\mathrm{CN}$. Four AA exchanges occurring in epitopes AA 55 to 72 and AA 106 to 122 of $7 \beta$-CN variants $\left(\mathrm{A}^{1}, \mathrm{~A}^{3}, \mathrm{~B}, \mathrm{C}, \mathrm{F}, \mathrm{G}\right.$, and $\left.\mathrm{H}^{2}\right)$ only induced positive IgE binding in serum 4 but without significant differences in the immunoreactivity between the mutated and the reference peptides.

The peptides AA 110 to 125 and AA 108 to 129 of $\beta-\mathrm{CN} \mathrm{A}^{1}$ and $\mathrm{A}^{2}$, as well as AA 109 to 123 and AA 103 to 123 of $\beta-\mathrm{CN} \mathrm{B}$, which were found to resist gastrointestinal digestion of $\beta-\mathrm{CN}$, reacted with $\mathrm{IgE}$ antibodies of serum 4 (Figure 2b). Significant variations in $\operatorname{IgE}$ binding could be demonstrated between peptides AA 103 to 122 and AA 104 to 123 of $\beta-\mathrm{CN}$ B, comprising the digested peptide AA 103 to 123, and peptides AA 108 to 127 and $\mathrm{AA} 110$ to 129 of $\beta-\mathrm{CN} \mathrm{A} \mathrm{A}^{1}$ and $\mathrm{A}^{2}$, representing the digested peptide AA 108 to 129, where peptides of variant $\mathrm{A}^{1}$ and $\mathrm{A}^{2}$ were not recognized by the $\operatorname{Ig} \mathrm{E}$ antibodies of serum 4 . 
Among the variant-specific $\kappa-\mathrm{CN}$ peptides, marked $\mathrm{IgE}$ binding was solely found for the $\kappa-\mathrm{CN}$ peptide AA 9 to 26 in serum 4 . Nevertheless, the substitution of an arginine $(\mathrm{R})$ by histidine $(\mathrm{H})$ in position 10 of $\kappa-\mathrm{CN} \mathrm{F}^{2}$ resulted in no significant change in immunoreactivity, as the remaining $\mathrm{IgE}$ binding was less than $15 \%$ compared with the reference peptide of $\kappa$-CN A (Figure 2c).

\section{Identification of Interspecies Differences on the Epitope Structure}

Due to the high degree of similarity in AA sequence between the known IgE-binding epitopes of caseins from cows and caseins from goats and water buffaloes, differences in their IgE-binding potential were investigated. The majority of sera showed IgE binding to $\alpha_{S 1}$ CN peptides of cows and the homologous counterpart of goats as well as water buffaloes. Some sera bound exclusively to peptides of cows, water buffaloes or goats. As illustrated in Figure 3a, b, and c, only the immunoreactivities of $\alpha_{S_{1}}$ and $\beta$-CN peptides were affected by the variation in the epitope sequences occurring in the different species. In most sera, a significant modification in IgE binding between epitopes of cows and the other species occurred if the peptides differed from each other in at least $2 \mathrm{AA}$. Nevertheless, in some epitopes, $1 \mathrm{AA}$ was sufficient to cause differences in the immunoreactivities between the epitopes of the species.

For several sera, marked diminished $\mathrm{IgE}$ binding ( $\geq 15 \%$ of $\mathrm{IgE}$ binding remaining compared with the reference peptides of cows) to $\alpha_{S_{1}}$ CN peptides AA 17 to 36 (sera 4 and 5), AA 64 to 78 (serum 4), AA 139 to 154 (sera 3 and 4 ) from goats as well as to $\alpha_{\mathrm{S} 1}-\mathrm{CN}$ peptides AA 139 to 154 (sera 3 and 4) and AA 173 to 192 (serum 2) from water buffaloes was found (Figure $3 \mathrm{a}$ and $\mathrm{b}$ ). In contrast, the $\alpha_{\mathrm{S}^{-}} \mathrm{CN}$ peptides AA 139 to 154 (sera 1 and 2), AA 173 to 192 (serum 7), and AA 175 to 194 (serum 7) of goats and water buffaloes were characterized by marked increased IgE binding compared with the peptides of cows.

Individual sera analyses recognized the cow $\alpha_{\mathrm{S}_{1}}-\mathrm{CN}$ peptides AA 34 to 48 (serum 5), AA 121 to 135 (serum 5), AA 159 to 174 (sera 1, 3, and 4), and AA 173 to 192 (sera 2 and 3). However, they had no or less IgE binding to the homologous peptides of goats and water buffaloes. In contrast, 3 sera showed IgE binding solely to the $\alpha_{\mathrm{S} 1}$-CN peptides AA 17 to 36 (serum 6), AA 173 to 192 (serum 6), AA 175 to 194 (serum 2), and AA 106 to 120 (serum 4) of goats or water buffaloes, or both, but not to the reference peptides of cows. In 3 sera, no significant differences in immunoreactivity were found between the $\alpha_{S_{1}}$ CN peptides AA 17 to 36 (serum 2), AA 173 to 192 (sera 2 and 4), and AA 175 to 194 (sera 4 and 6 ) of the 3 species.
For $\beta-\mathrm{CN}$, significant IgE binding was seen for peptide AA 16 to 35 of goats and water buffaloes (sera 4 and 7), as indicated in Figure 3c. Additionally, serum 4 reacted with the $\beta$-CN peptide AA 55 to 72 of cows and water buffaloes. However, no reaction against the homologous peptide of goats could be observed. On the other hand, significant IgE binding was only detected for peptide AA 135 to 149 (serum 4) of goats.

\section{DISCUSSION}

\section{Identification of IgE-Binding Epitopes in Patient Sera Samples}

In this study, each individual serum had a heterogeneous IgE recognition pattern in terms of diversity and intensity of epitope binding. This agrees with previous observations and might be associated with clinical features of CMA, such as the course or the severity of allergic reactions (Savilahti et al., 2010; Wang et al., 2010). Most sera were monosensitized toward $\alpha_{\mathrm{S1}}-\mathrm{CN}$, as $\mathrm{IgE}$ binding was mainly seen for $\alpha_{\mathrm{S1}_{1}} \mathrm{CN}$ peptides, which is consistent with the fact that $\alpha_{\mathrm{S}_{1}} \mathrm{CN}$ has been described as the main allergen among the 4 caseins (Docena et al., 1996; Gaudin et al., 2008, Schulmeister et al., 2009).

The strongest fluorescence intensities and binding to most of casein peptides were obtained with serum 4 . Nevertheless, for most samples, weak signal intensities on the peptide microarray were observed, but showed significant higher signals compared with noise. Conceivably, this is caused by $\operatorname{IgG}$ antibodies, which compete with the binding of serum $\operatorname{IgE}$ to the specific epitope peptides. It has been demonstrated that $\operatorname{IgE}$ and $\operatorname{IgG}$ antibodies recognize the same or similar epitopes on the various CMP (Chatchatee et al., 2001a,b; Savilahti et al., 2010). Due to this fact, it also might be that additionally to serum 4 , further sera would react with other $\alpha_{\mathrm{S}^{-}}, \beta-$, or $\kappa$-CN peptides. Therefore, the possible competing interactions between $\operatorname{IgE}$ and $\operatorname{Ig} G$ antibodies had to be considered in further analyses.

\section{Identification of Variant-Specific Differences on the Epitope Structure}

To date, the only treatment of CMA is strict avoidance of all CMP, including CMP-derived infant formulas and other dairy products. However, this carries the risk of inadequate nutrient intake, such as calcium or a negative calorie:protein ratio and AA composition (Fiocchi et al., 2010). Thus, the identification of a suitable protein source or safe cow milk substitutes is an important aim for pediatricians and nutritionists to ensure a balanced diet for CMA patients. Depending on the nature of the 
allergy and as a consequence of the specific sensitization pattern of an individual, the best alternative diet has to be defined for each patient (Restani et al., 2009; du Toit et al., 2010). In the present study, it was demonstrated that the genetic polymorphism has influence on the immunoreactivity of some casein epitopes and peptides resisting gastrointestinal digestion, although with significant differences between individual sera (Table 2). A marked heterogeneity in $\operatorname{IgE}$ binding was seen for the variant-specific epitopes AA 4 to 23 of $\alpha_{\mathrm{S}_{1}} \mathrm{CN}$ A as well as AA 173 to 192 and $\mathrm{AA} 175$ to 194 of $\alpha_{\mathrm{S}^{-}} \mathrm{CN} \mathrm{C}$ and $\mathrm{E}$ because the deletions and substitutions resulted in abrogation or decreased or increased $\mathrm{IgE}$ binding in particular sera. This is of importance, as the corresponding epitopes AA 17 to 36 and AA 173 to 194 of the reference protein $\alpha_{S 1}$-CN B were identified as immunodominant IgE-binding regions, not only in this study but also by Chatchatee et al. (2001a), because they were recognized with the highest IgE-binding intensities in the majority of patients. Therefore, abrogated or increased $\operatorname{IgE}$ binding to both epitopes in $\alpha_{S_{1}}-\mathrm{CN} \mathrm{A}, \mathrm{C}$, and $\mathrm{E}$ may change the allergenicity of the whole proteins in most patients. In contrast, epitope AA 83 to 102 of $\alpha_{\mathrm{SI}^{-}} \mathrm{CN}$ I showed almost identical IgE binding between individual sera. The AA substitution led to a significant increase in $\mathrm{IgE}$ binding in 3 of the 7 sera. This is quite surprising, as the substituted AA, glutamic acid (E), and aspartic acid (D) are both polar, acidic, and have the same hydrophobicity and, consequently, no change in the immunoreactivity between epitope AA 83 to 102 of $\alpha_{\mathrm{S}_{1}} \mathrm{CN}$ I and B may be expected. However, in this epitope, the substitution is located at position 84 at the $\mathrm{N}$ terminus of the epitope, which confirms the observation of Cocco et al. (2003). They reported that substitutions of hydrophobic AA in the central portion of epitopes in $\alpha_{\mathrm{S}_{1}} \mathrm{CN}$ were most likely to induce a loss of antibody binding, whereas a small increase in IgE binding was observed for some substitutions at the periphery of the epitope.

For the majority of variant-specific peptides, no significant differences in IgE binding could be found compared with the corresponding reference peptides. This can be explained by the fact that the occurrence of only 1 AA substitution in these epitopes is not sufficient to alter their IgE-binding properties. In general, all sera showed variations in the IgE-binding intensities when peptides differed from each other by 2 AA. For example, with serum 4, more $\operatorname{IgE}$ binding was determined for peptides AA 173 to $192>$ AA 175 to $194>$ AA 174 to 193 of $\alpha_{\mathrm{S1}^{-}} \mathrm{CN}$ B and for peptides AA 173 to $192>$ AA 175 to $194>$ AA 179 to 198 of $\alpha_{\mathrm{S}_{1}}$ CN C. This indicates that for $\alpha_{S_{1}}-\mathrm{CN}$, a minimum of $2 \mathrm{AA}$ have to be changed to alter the immunoreactivity in the majority of epitopes, which is in agreement with the results of the mutational analysis of $\alpha_{S 1}-\mathrm{CN}$ by Cocco et al. (2003). However, for the bulk of epitopes in $\beta$ - and $\kappa-\mathrm{CN}$, as well as in the peanut allergens Ara h1, Ara h2, and Ara h3, 1 AA substitution has been detected to be sufficient for inducing a significant modification in IgE binding (Burks et al., 1997; Stanley et al., 1997; Cocco et al., 2007; Han et al., 2008).

Some of the $\alpha_{\mathrm{S1}^{-}}$and $\beta$-CN peptides, which were found to resist in vitro gastrointestinal digestion (Lisson et al., 2013, 2014), showed positive IgE binding on microarray immunoassay, suggesting that these digested low-molecular weight peptides retain an allergenic potential, as was also described for other food allergens (Bøgh et al., 2009, 2012; Martos et al., 2012). In the current study, peptides $13 \mathrm{AA}$ in length, such as AA 184 to 196 of $\alpha_{\mathrm{S}_{1}}-\mathrm{CN} \mathrm{B}$ as well as AA 180 to 193 of $\alpha_{\mathrm{S}_{1}-} \mathrm{CN} B$ and $\mathrm{C}$, displayed significant $\operatorname{IgE}$ binding on the peptide microarray, even if immunoreactivity was lower compared with the longer peptides (e.g., AA 173 to 192 or AA 175 to 194). It is generally thought that peptides have to be approximately 3,500 Da (30 AA residues) in length and must contain at least 2 IgE-binding epitopes to induce cross-linking of the $\operatorname{Ig} \mathrm{E}$ receptors for stimulating an immune response (Huby et al., 2000). Nevertheless, it has been reported that immunization with free peptides as small as 6 to $14 \mathrm{AA}$ long induced an acceptable antibody response (Atassi and Young, 1985; Muller, 1999). This was also demonstrated for the peanut allergen Ara h1, where peptides of less than 2,000 Da were able to sensitize and elicit allergic reactions (B $\emptyset \mathrm{gh}$ et al., 2009, 2012). Results of the present study suggest that this could also apply to casein peptides. Thus, they probably do not need to survive the digestion process as large fragments to react with the immune system, which might contribute to the high sensitization rate to the caseins and explain why caseins are such potent allergens despite their excellent digestibility.

One limitation of the current study was the small number of tested sera, most of which reacted solely with $\alpha_{\mathrm{S} 1}-\mathrm{CN}$. Among the 16 sera used in this study, 7 displayed positive IgE binding on the microarray and only 2 sera exhibited positive $\operatorname{IgE}$ binding to $\beta$ - and $\kappa$-CN peptides. Thus, it is entirely possible that some epitopes of $\beta$ - and $\kappa$-CN variants differ in their allergenic properties when tested with other sera. All sera had milk-specific $\operatorname{IgE} \geq 95.5 \mathrm{kU}_{\mathrm{A}} / \mathrm{L}$, meaning that low or lacking signals on the microarray were due to confounding factors in the methods rather than the quality of the sera. To evaluate differences in immunoreactivity between the variant-specific epitopes, further investigations with a larger number of patient sera known to have $\operatorname{IgE}$ against both proteins are needed.

In this study, decreased, abrogated, or even higher IgE binding to the immunodominant epitopes AA 17 
to 36 , AA 173 to 192 , and AA 175 to 194 in $\alpha_{\mathrm{S}^{-}} \mathrm{CN}$ A, C, or E was identified (Table 2). For example, serum 2 showed significant lower $\operatorname{IgE}$ binding to peptide AA 4 to 23 of $\alpha_{\mathrm{S}_{1}} \mathrm{CN}$ A than to peptide AA 17 to 36 of $\alpha_{\mathrm{S} 1}-\mathrm{CN}$ B, C, and E. Furthermore, peptide AA 175 to 194 of variant A, sharing the same sequence with peptide of $\alpha_{S_{1}}$ CN B, was no longer recognized from $\operatorname{IgE}$ antibodies of serum 2, whereas significant IgE binding was found to the corresponding peptide of $\alpha_{\mathrm{S}_{1}-\mathrm{CN} \mathrm{C}}$ and $\mathrm{E}$. As a consequence, it is likely that the decreased and abrogated $\operatorname{IgE}$ binding to these 2 immunodominant epitopes in $\alpha_{S 1}-\mathrm{CN} A$ changed the allergenicity of the whole protein and, thus, milk from cows with genotypes $\alpha_{\mathrm{S} 1}$-CN AA might be characterized by a lower or, as was detected for sera 4 and 6 , higher allergenicity. This could be also relevant for cows carrying the genotype $\alpha_{S_{1}}-\mathrm{CN}$ CC and EE regarding the differences in $\operatorname{IgE}$ binding to epitopes AA 173 to 192 and AA 175 to 194. In the case of reduced allergenic potential, these protein variants might be suitable for the production of hypoallergenic milk or as a basis for infant formulas for a well-selected group of allergic patients monosensitized to $\alpha_{\mathrm{S} 1}-\mathrm{CN}$. This does not necessarily mean that whole milk has to be used, but rather individual milk protein fractions, which could be used for specific processed products. To achieve this aim, selection and breeding

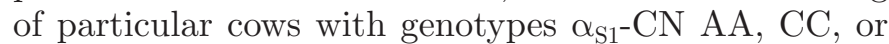
$\mathrm{EE}$ would be necessary. However, $\alpha_{\mathrm{S1}^{-}} \mathrm{CN} \mathrm{A}$ is rather common, but occurs with low frequencies in HolsteinFriesian and German Red cows (Erhardt, 1993). In contrast, $\alpha_{\mathrm{S} 1}-\mathrm{CN} \mathrm{C}$ is very common in all main breeds, with higher frequencies such as 0.45 in Jerseys or 0.2 in Pinzgauers and $\alpha_{\mathrm{S}^{-}} \mathrm{CN} \mathrm{E}$ has been reported only in Bos grunniens (Caroli et al., 2009). There is already a kind of milk with a specific genotype on the market. Since 2003, $\mathrm{A}^{2}$ milk, containing only the $\mathrm{A}^{2}$ variant of $\beta-\mathrm{CN}$, has been marked in New Zealand and Australia because epidemiological evidence implies that $\mathrm{A}^{2}$ milk is better for human health than $\mathrm{A}^{1}$ milk (A2 Corporation Ltd., Auckland, New Zealand), although the European Food Safety Authority could not establish a relationship between $\mathrm{A}^{1}$ milk and increased disease (EFSA, 2009). Because of the fact that IgE antibodies from individual patients also displayed increased binding to several mutated epitopes in the current study makes it difficult to consider specific genetic variants as a safe protein source for all patients with CMA.

\section{Identification of Interspecies Differences on the Epitope Structure}

In the quest to identify alternative protein sources for patients with CMA, there has been an increasing focus on the use of proteins from other species. Neverthe- less, clinical cross-reactivity exists between milk from cows, sheep, goats, and water buffaloes (Järvinen and Chatchatee, 2009; Restani et al., 2009), which is due to the high degree of AA sequence homology between the proteins from cows and the other Bovidae (96.1\% for buffaloes, $91.1 \%$ for sheep, and $87.6 \%$ for goats; Restani et al., 2009). Most patients who are sensitized to cow milk do not tolerate goat or sheep milk (BellioniBusinco et al., 1999; Carroccio et al., 1999). In the present study, we found that several sera reacted with both cow peptides and the corresponding peptides of goats and water buffaloes, demonstrating cross-reactivity or co-sensitization. However, in the majority of sera, individual epitopes from goats and water buffaloes showed lower immunoreactivity compared with epitopes from cows, which suggests reduced allergenic activity of ${ }_{1}$-CN from goat. These findings are in agreement with the results of other studies (Spuergin et al., 1997; Bevilacqua et al., 2001; Lara-Villoslada, et al., 2004; Sanz Ceballos et al., 2009; Hodgkinson et al., 2012). The lower allergenic potential of goat milk could be attributable, at least in part, to the high genetic polymorphism of $\alpha_{S 1}-\mathrm{CN}$ that occurs also in goat milk proteins. In goat milk, genetic variants of $\alpha_{\mathrm{S} 1}-\mathrm{CN}$ are characterized by high $(3.5 \mathrm{~g} / \mathrm{L})$, medium $(1.1 \mathrm{~g} / \mathrm{L})$, low $(0.45 \mathrm{~g} / \mathrm{L})$, and null quantities of this protein (Ballabio et al., 2011). Several studies demonstrated that goat milk with low or null $\alpha_{\mathrm{S} 1}-\mathrm{CN}$ content has reduced allergenic potential. Ballabio et al. (2011) investigated the allergenic potency of goat milk with different $\alpha_{\mathrm{S1}}-\mathrm{CN}$ genotypes. They detected lower immunoreactions to $\alpha_{\mathrm{S} 1}-\mathrm{CN} 0_{1} 0_{1}$ (null content of $\alpha_{\mathrm{S}_{1}} \mathrm{CN}$ ) and $0_{1} \mathrm{~F}$ (reduced content of $\left.\alpha_{S_{1}-} \mathrm{CN}\right)$ genotypes compared with goat milk samples containing $\alpha_{\mathrm{S}_{1}} \mathrm{CN} \mathrm{BB}, \mathrm{BE}, \mathrm{EE}$, or FF. By using guinea pig models (Bevilacqua et al., 2001; Sanz Ceballos et al., 2009) and murine models (Lara-Villoslada et al., 2004; Hodgkinson et al., 2012), it could be also shown that milk from goats producing low levels of $\alpha_{\mathrm{S}^{-}} \mathrm{CN}$ is potential less allergenic than milk from cows or goats containing higher levels of this protein. This may be one reason why some cow milk-allergic children are able to tolerate goat milk (Restani, 2004).

Moreover, in the present study, individual sera $\operatorname{IgE}$ only recognized $\alpha_{\mathrm{S}_{1}}-\mathrm{CN}$ and $\beta-\mathrm{CN}$ peptides of goats or water buffaloes but not the corresponding cow milk peptides. This indicates higher allergenicity of both proteins from the nonbovine species and might explain the observation that some patients have a selective allergy to goat or sheep milk but not to cow milk, as has been reported by others (Alvarez and Lombardero, 2002; Bidat et al., 2003; Ah-Leung et al., 2006; Mori et al., 2013).

Interestingly, in serum 4, significant IgE binding was found to the $\alpha_{S_{1}}$ CN peptide AA 106 to 120 of water 
buffaloes. In comparison with the corresponding peptides of cows and goats, showing no $\mathrm{IgE}$ binding in any serum, this peptide lacks a phosphorylated serine at position 115. Conflicting results exist about the role of phosphorylation in allergy. Cases et al. (2011) demonstrated that phosphorylation reduces the allergenicity of cow caseins in children with selective allergy to goat and sheep milk. In contrast, it has been assumed that the major phosphorylation sites act as important allergenic epitopes in the caseins, as dephosphorylation significantly diminish their allergenicity (Bernard et al., 2000), which is in concordance with the results of the present study. Twenty peptides were synthesized in phosphorylated and dephosphorylated form, but only 1 peptide (AA 106 to 120 of $\alpha_{\mathrm{S}^{-}} \mathrm{CN}$ ) revealed differences in immunoreactivity. The other peptides displayed no significant IgE binding on the microarray immunoassay. A possible explanation is that 17 of the 20 peptides were from $\alpha_{\mathrm{S}_{2}}, \beta$-, and $\kappa$-CN and, therefore, not recognized by the $\operatorname{Ig} \mathrm{E}$ antibodies because most sera tested in this study were sensitized against $\alpha_{\mathrm{S} 1}-\mathrm{CN}$.

\section{CONCLUSIONS}

Genetic polymorphisms of caseins influence the allergenic potential of some immunodominant epitopes. Single AA substitutions or deletion resulted in a loss or decrease or increase in immunoreactivity in some $\alpha_{\mathrm{S1}^{-}}$ and $\beta$-CN epitopes with the tested sera. The genetic polymorphism of caseins should be taken into account in the search for a suitable protein source for CMA patients. However, a heterogeneous pattern of $\operatorname{IgE}$ binding to the variant-specific peptides was found between the individual sera. Thus, further clinical studies with more patient sera are needed to verify their suitability for CMA patients. The results of the present study confirm that the milk of goats and water buffaloes harbor an allergenic potential due to cross-reactivity between the proteins and are, consequently, not an appropriate replacement for patients with CMA. Nevertheless, these species are also characterized by genetic polymorphisms that affect the allergenic properties of their IgE-binding epitopes, as has been already shown for goat milk.

\section{ACKNOWLEDGMENTS}

This work is supported by the German Research Foundation (Bonn, Germany; DFG ER 122/13-1). We thank Paul von Hoegen and Johannes Zerweck from JPT Peptide Technologies GmbH (Berlin, Germany) for valuable discussion regarding microarray technology and Andreas Nockher and Michael Zemlin from the University Hospital Marburg (Germany) as well as Andreas Jung from the University Hospital Gießen (Germany) for providing sera.

\section{REFERENCES}

Ah-Leung, S., H. Bernard, E. Bidat, E. Paty, F. Rancé, P. Scheinmann, and J. M. Wal. 2006. Allergy to goat and sheep milk without allergy to cow's milk. Allergy 61:1358-1365.

Alvarez, M. J., and M. Lombardero. 2002. IgE-mediated anaphylaxis to sheep's and goat's milk. Allergy 57:1091-1092.

Atassi, M. Z., and C. R. Young. 1985. Discovery and implications of the immunogenicity of free small synthetic peptides: Powerful tools for manipulating the immune system and for production of antibodies and $\mathrm{T}$ cells of preselected submolecular specificities. Crit. Rev. Immunol. 5:387-409.

Ballabio, C., S. Chessa, D. Rignanese, C. Gigliotti, G. Pagnacco, L. Terracciano, A. Fiocchi, P. Restani, and A. M. Caroli. 2011. Goat milk allergenicity as a function of $\alpha_{S 1}$-casein genetic polymorphism. J. Dairy Sci. 94:998-1004.

Bellioni-Businco, B., R. Paganelli, P. Lucenti, P. G. Giampietro, H. Perborn, and L. Businco. 1999. Allergenicity of goat's milk in children with cow's milk allergy. J. Allergy Clin. Immunol. 103:1191-1194.

Bernard, H., H. Meisel, C. Creminon, and J. M. Wal. 2000. Posttranslational phosphorylation affects the $\operatorname{IgE}$ binding capacity of caseins. FEBS Lett. 467:239-244.

Bevilacqua, C., P. Martin, C. Candalh, J. Fauquant, M. Piot, A. M. Roucayrol, F. Pilla, and M. Heyman. 2001. Goat's milk of defective $\alpha_{S_{1}}$-casein genotype decreases intestinal and systemic sensitization to $\beta$-lactoglobulin in guinea pigs. J. Dairy Res. 68:217-227.

Bidat, E., F. Rancé, T. Baranès, and S. Goulamhoussen. 2003. Goat's milk and sheep's milk allergies in children in the absence of cow's milk allergy. Rev. Fr. Allergol. Immunol. Clin. 43:273-277.

Bøgh, K. L., V. Barkholt, N. M. Rigby, E. N. C. Mills, and C. B. Madsen. 2012. Digested Ara h 1 loses sensitizing capacity when separated into fractions. J. Agric. Food Chem. 60:2934-2942.

Bøgh, K. L., S. Kroghsbo, L. Dahl, N. M. Rigby, V. Barkholt, E. N. C. Mills, and C. B. Madsen. 2009. Digested Ara h 1 has sensitizing capacity in Brown Norway rats. Clin. Exp. Allergy 39:1611-1621.

Burks, A. W., D. Shin. G. Cockrell, J. S. Stanley, R. M. Helm, and G. A. Bannon. 1997. Mapping and mutational analysis of the IgEbinding epitopes on Ara h 1, a legume vicilin protein and a major allergen in peanut hypersensitivity. Eur. J. Biochem. 245:334-339.

Busse, P. J., K.-M. Järvinen, L. Vila, K. Beyer, and H. A. Sampson. 2002. Identification of sequential IgE-binding epitopes on bovine $\alpha_{\mathrm{s} 2}$-casein in cow's milk allergic patients. Int. Arch. Allergy Immunol. 129:93-96.

Caroli, A. M., S. Chessa, and G. J. Erhardt. 2009. Invited review: Milk protein polymorphisms in cattle: Effect on animal breeding and human nutrition. J. Dairy Sci. 92:5335-5352.

Carroccio, A., F. Cavataio, and G. Iacono. 1999. Cross-reactivity between milk proteins of different animals. Clin. Exp. Allergy 29:1014-1016.

Cases, B., C. García-Ara, M. T. Boyano, M. Pérez-Gordo, M. Pedrosa, F. Vivanco, S. Quirce, and C. Pastor-Vargas. 2011. Phosphorylation reduces the allergenicity of cow casein in children with selective allergy to goat and sheep milk. J. Investig. Allergol. Clin. Immunol. 21:398-400.

Cerecedo, I., J. Zamora, W. G. Shreffler, J. Lin, L. Bardina, M. C. Dieguez, J. Wang, A. Muriel, B. de La Hoz, and H. A. Sampson. 2008. Mapping of the IgE and IgG4 sequential epitopes of milk allergens with a peptide microarray-based immunoassay. J. Allergy Clin. Immunol. 122:589-594.

Chatchatee, P., K.-M. Järvinen, L. Bardina, K. Beyer, and H. A. Sampson. 2001a. Identification of IgE- and IgG-binding epitopes on $\alpha_{s 1}$-casein: Differences in patients with persistent and transient cow's milk allergy. J. Allergy Clin. Immunol. 107:379-383.

Chatchatee, P., K. M. Järvinen, L. Bardina, L. Vila, K. Beyer, and H. A. Sampson. 2001b. Identification of $\operatorname{IgE}$ and $\operatorname{IgG}$ binding epitopes 
on beta- and kappa-casein in cow's milk allergic patients. Clin. Exp. Allergy 31:1256-1262.

Cocco, R. R., K. Järvinen, N. Han, K. Beyer, and H. A. Sampson. 2007. Mutational analysis of immunoglobulin E-binding epitopes of beta-casein and beta-lactoglobulin showed a heterogeneous pattern of critical amino acids between individual patients and pooled sera. Clin. Exp. Allergy 37:831-838.

Cocco, R. R., K. Järvinen, H. A. Sampson, and K. Beyer. 2003. Mutational analysis of major, sequential IgE-binding epitopes in alpha s1-casein, a major cow's milk allergen. J. Allergy Clin. Immunol. 112:433-437.

de Boissieu, D., P. Matarazzo, and C. Dupont. 1997. Allergy to extensively hydrolyzed cow milk proteins in infants: Identification and treatment with an amino acid-based formula. J. Pediatr. 131:744-747.

Docena, G. H., R. Fernandez, F. G. Chirdo, and C. A. Fossati. 1996. Identification of casein as the major allergenic and antigenic protein of cow's milk. Allergy 51:412-416.

du Toit, G., R. Meyer, N. Shah, R. G. Heine, M. A. Thomson, G. Lack, and A. T. Fox. 2010. Identifying and managing cow's milk protein allergy. Arch. Dis. Child. Educ. Pract. Ed. 95:134-144.

Dupont, D., G. Mandalari, D. Molle, J. Jardin, J. Léonil, R. M. Faulks, M. S. J. Wickham, E. N. C. Mills, and A. R. Mackie. 2010a. Comparative resistance of food proteins to adult and infant in vitro digestion models. Mol. Nutr. Food Res. 54:767-780.

Dupont, D., G. Mandalari, D. Mollé, J. Jardin, O. Rolet-Répécaud, G. Duboz, J. Léonil, C. E. N. Mills, and A. R. Mackie. 2010b. Food processing increases casein resistance to simulated infant digestion. Mol. Nutr. Food Res. 54:1677-1689.

EFSA (European Food Safety Authority). 2009. Review of the potential health impact of $\beta$-casomorphins and related peptides. EFSA Scientific Report 231:1-107.

Erhardt, G. 1993. Allele frequencies of milk proteins in German cattle breeds and demonstration of $\alpha_{\mathrm{s} 2}$-casein variants by isoelectric focusing. Arch. Tierz. 36:145-152.

Fiocchi, A., H. J. Schünemann, J. Brozek, P. Restani, K. Beyer, R. Troncone, A. Martelli, L. Terracciano, S. L. Bahna, F. Rancé, M. Ebisawa, R. G. Heine, A. Assa'ad, H. Sampson, E. Verduci, G. R. Bouygue, C. Baena-Cagnani, W. Canonica, and R. F. Lockey. 2010. Diagnosis and Rationale for Action Against Cow's Milk Allergy (DRACMA): A summary report. J. Allergy Clin. Immunol. 126:1119-1128.

Frank, R., and H. Overwin. 1996. SPOT synthesis: Epitope analysis with arrays of synthetic peptides prepared on cellulose membranes. Methods Mol. Biol. 66:149-169.

Gaudin, J.-C., H. Rabesona, Y. Choiset, G. Yeretssian, J. Chobert, V. Sakanyan, M. Drouet, and T. Haertlé. 2008. Assessment of the immunoglobulin E-mediated immune response to milk-specific proteins in allergic patients using microarrays. Clin. Exp. Allergy 38:686-693.

Han, N., K. M. Järvinen, R. R. Cocco, P. J. Busse, H. A. Sampson, and K. Beyer. 2008. Identification of amino acids critical for IgEbinding to sequential epitopes of bovine kappa-casein and the similarity of these epitopes to the corresponding human kappa-casein sequence. Allergy 63:198-204.

Heck, J. M. L., A. Schennink, H. J. F. van Valenberg, H. Bovenhuis, M. H. P. W. Visker, J. A. M. van Arendonk, and A. C. M. van Hooijdonk. 2009. Effects of milk protein variants on the protein composition of bovine milk. J. Dairy Sci. 92:1192-1202.

Hodgkinson, A. J., N. A. McDonald, L. J. Kivits, D. R. Hurford, S. Fahey, and C. Prosser. 2012. Allergic responses induced by goat milk $\alpha_{\mathrm{S}_{1}}$-casein in a murine model of gastrointestinal atopy. J. Dairy Sci. 95:83-90.

Hoffman, K. M., and H. A. Sampson. 1997. Serum specific-IgE antibodies to peptides detected in a casein hydrolysate formula. Pediatr. Allergy Immunol. 8:185-189.

Huby, R. D., R. J. Dearman, and I. Kimber. 2000. Why are some proteins allergens? Toxicol. Sci. 55:235-246.

Järvinen, K. M., and P. Chatchatee. 2009. Mammalian milk allergy: Clinical suspicion, cross-reactivities and diagnosis. Curr. Opin. Allergy Clin. Immunol. 9:251-258.
Jinsmaa, Y., and M. Yoshikawa. 1999. Enzymatic release of neocasomorphin and $\beta$-casomorphin from bovine $\beta$-casein. Peptides 20:957-962.

Lara-Villoslada, F., M. Olivares, J. Jiménez, J. Boza, and J. Xaus. 2004. Goat milk is less immunogenic than cow milk in a murine model of atopy. J. Pediatr. Gastroenterol. Nutr. 39:354-360.

Lin, J., L. Bardina, W. G. Shreffler, D. A. Andreae, Y. Ge, J. Wang, F. M. Bruni, Z. Fu, Y. Han, and H. A. Sampson. 2009. Development of a novel peptide microarray for large-scale epitope mapping of food allergens. J. Allergy Clin. Immunol. 124:315-322.

Lisson, M., G. Lochnit, and G. Erhardt. 2013. Genetic variants of bovine $\beta$ - and $\kappa$-casein result in different immunoglobulin E-binding epitopes after in vitro gastrointestinal digestion. J. Dairy Sci. 96:5532-5543. http://dx.doi.org/10.3168/jds.2013-6684.

Lisson, M., G. Lochnit, and G. Erhardt. 2014. In vitro gastrointestinal digestion of bovine $\alpha_{S 1^{-}}$and $\alpha_{S 2^{-}}$casein variants gives rise to different IgE-binding epitopes. Int. Dairy J. 34:47-55. http://dx.doi. org/10.1016/j.idairyj.2013.06.012.

Martin, P., M. Szymanowska, L. Zwierzchowski, and C. Leroux. 2002. The impact of genetic polymorphisms on the protein composition of ruminant milks. Reprod. Nutr. Dev. 42:433-459.

Martos, G., C. Pineda-Vadillo, B. Miralles, E. Alonso-Lebrero, R. López-Fandiño, E. Molina, and J. Belloque. 2012. Identification of an $\operatorname{IgE}$ reactive peptide in hen egg riboflavin binding protein subjected to simulated gastrointestinal digestion. J. Agric. Food Chem. 60:5215-5220.

Mori, F., P. Restani, N. Pucci, C. Ballabio, F. Uberti, E. Penas, and E. Novembre. 2013. Allergy to all mammalian Bovidae proteins but cow's milk in a child. Allergol. Immunopathol. (Madr.) 41:349 350. http://dx.doi.org/10.1016/j.aller.2012.07.014.

Muller, S. 1999. Immunization with peptides. Lab. Techniques Biochem. Molec. Biol. 28:133-177.

Osterballe, M., T. K. Hansen, C. G. Mortz, A. Høst, and C. Bindslev-Jensen. 2005. The prevalence of food hypersensitivity in an unselected population of children and adults. Pediatr. Allergy Immunol. 16:567-573.

Ragno, V., P. G. Giampietro, G. Bruno, and L. Businco. 1993. Allergenicity of milk protein hydrolysate formulae in children with cow's milk allergy. Eur. J. Pediatr. 152:760-762.

Restani, P. 2004. Goat milk allergenicity. J. Pediatr. Gastroenterol. Nutr. 39:323-324.

Restani, P., C. Ballabio, C. Di Lorenzo, S. Tripodi, and A. Fiocchi. 2009. Molecular aspects of milk allergens and their role in clinical events. Anal. Bioanal. Chem. 395:47-56.

Sanz Ceballos, L., M. R. Sanz Sampelayo, F. Gil Extremera, and M. Rodríguez Osorio. 2009. Evaluation of the allergenicity of goat milk, cow milk, and their lactosera in a guinea pig model. J. Dairy Sci. 92:837-846.

Savilahti, E. M., V. Rantanen, J. S. Lin, S. Karinen, K. M. Saarinen, M. Goldis, M. J. Mäkelä, S. Hautaniemi, E. Savilahti, and H. A. Sampson. 2010. Early recovery from cow's milk allergy is associated with decreasing $\operatorname{IgE}$ and increasing IgG4 binding to cow's milk epitopes. J. Allergy Clin. Immunol. 125:1315-1321.

Savilahti, E. M., and E. Savilahti. 2013. Development of natural tolerance and induced desensitization in cow's milk allergy. Pediatr. Allergy Immunol. 24:114-121.

Schulmeister, U., H. Hochwallner, I. Swoboda, M. Focke-Tejkl, B. Geller, M. Nystrand, A. Härlin, J. Thalhamer, S. Scheiblhofer, W. Keller, B. Niggemann, S. Quirce, C. Ebner, A. Mari, G. Pauli, U. Herz, R. Valenta, and S. Spitzauer. 2009. Cloning, expression, and mapping of allergenic determinants of alphaS1-casein, a major cow's milk allergen. J. Immunol. 182:7019-7029.

Shek, L. P. C., L. Bardina, R. Castro, H. A. Sampson, and K. Beyer. 2005. Humoral and cellular responses to cow milk proteins in patients with milk-induced IgE-mediated and non-IgE-mediated disorders. Allergy 60:912-919.

Skripak, J. M., E. C. Matsui, K. Mudd, and R. A. Wood. 2007. The natural history of IgE-mediated cow's milk allergy. J. Allergy Clin. Immunol. 120:1172-1177. 
Spuergin, P., M. Walter, E. Schiltz, K. Deichmann, J. Forster, and H. Mueller. 1997. Allergenicity of alpha-caseins from cow, sheep, and goat. Allergy 52:293-298.

Stanley, J. S., N. King, A. W. Burks, S. K. Huang, H. Sampson, G. Cockrell, R. M. Helm, C. M. West, and G. A. Bannon. 1997. Identification and mutational analysis of the immunodominant IgE binding epitopes of the major peanut allergen Ara h 2. Arch. Biochem. Biophys. 342:244-253.

Tulipano, G., O. Bulgari, S. Chessa, A. Nardone, D. Cocchi, and A. Caroli. 2010. Direct effects of casein phosphopeptides on growth and differentiation of in vitro cultured osteoblastic cells (MC3T3E1). Regul. Pept. 160:168-174.
Wang, J., J. Lin, L. Bardina, M. Goldis, A. Nowak-Węgrzyn, W. G. Shreffler, and H. A. Sampson. 2010. Correlation of IgE/IgG4 milk epitopes and affinity of milk-specific $\operatorname{IgE}$ antibodies with different phenotypes of clinical milk allergy. J. Allergy Clin. Immunol. 125:695-702.

Weimann, C., H. Meisel, and G. Erhardt. 2009. Short communication: Bovine $\kappa$-casein variants result in different angiotensin I converting enzyme (ACE) inhibitory peptides. J. Dairy Sci. 92:1885-1888.

Wenschuh, H., R. Volkmer-Engert, M. Schmidt, M. Schulz, J. Schneider-Mergener, and U. Reineke. 2000. Coherent membrane supports for parallel microsynthesis and screening of bioactive peptides. Biopolymers 55:188-206. 